\title{
Adverse events following mass antibiotic prophylaxis during a Group A Streptococcus outbreak in the Canadian Forces Leadership and Recruit School
}

\author{
Diane Lu ${ }^{1 *}$ Barbara Strauss' ${ }^{1}$, Kristen Simkus', Martin Tepper ${ }^{1}$, François Gagnon², \\ Noémie Johnson ${ }^{2}$, Eric Girard ${ }^{2}$, Kirsten Barnes ${ }^{1}$
}

\section{Abstract}

Background: Between December 2016 and March 2018, two outbreaks of Group A Streptococcus (GAS) infection occurred at the Canadian Forces Leadership and Recruit School. A voluntary mass antibiotic prophylaxis (MAP) program was implemented in March 2018, to interrupt an ongoing GAS outbreak, and to prevent future outbreaks.

Methods: Instructors and recruits were offered a one-time intramuscular injection of 1.2 million units penicillin $G$ benzathine (PGB). Individuals with a penicillin allergy were offered azithromycin; $500 \mathrm{mg}$ orally once weekly for four consecutive weeks. Instructors and recruits were also asked to complete a voluntary and anonymous survey one week after receipt of MAP, to detect MAP-related adverse events.

Results: MAP was offered to 2,749 individuals; 2,707 of whom agreed to receive it $(98.5 \%$ uptake). The majority of personnel experienced adverse events in the days following MAP; 92.3\% of personnel who received PGB reported localized pain at the injection site, and $70.2 \%$ of personnel who received azithromycin reported gastrointestinal symptoms. However, only five cases of serious adverse events were reported, and less than $1 \%$ of recruits could not complete their basic military training course because of MAP-related adverse events.

Conclusion: The MAP program implemented in March 2018 was the first of its kind in the Canadian Armed Forces, and the largest single use of PGB in a defined group in Canada. It resulted in very few serious adverse events and with minimal impact on military recruits' successful completion of recruit training.
This work is licensed under a Creative Commons Attribution 4.0 Internationa License.

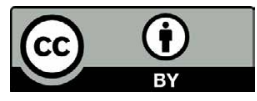

Affiliations

1 Directorate Force Health Protection, Canadian Forces Health Services, Ottawa, ON

241 Centre des Services de santé des Forces canadiennes, Richelain, QC

\section{*Correspondence:}

diane.lu@forces.gc.ca

Suggested citation: Lu D, Strauss B, Simkus K, Tepper M, Gagnon F, Johnson N, Girard E, Barnes K. Adverse events following mass antibiotic prophylaxis during a Group A Streptococcus outbreak in the Canadian Forces Leadership and Recruit School. Can Commun Dis Rep 2020;46(9):264-71.

https://doi.org/10.14745/ccdr.v46i09a03

Keywords: infectious disease outbreaks, military recruits, Canada, Streptococcus pyogenes, mass antibiotic prophylaxis, adverse events

\section{Introduction}

Group A Streptococcus (GAS) is a beta-hemolytic Gram-positive bacteria that causes infections that typically present as pharyngitis or tonsillitis $(1,2)$. However, it can cause serious disease in otherwise healthy adults. Outbreaks of invasive GAS (iGAS) in the United States (US) military recruit populations have been documented dating back to the 1940s (3). Risk factors associated with iGAS in military environments include close sleeping quarters, training under stressful conditions and close contact exposure (2-7). Mass antibiotic prophylaxis (MAP) has previously been used to effectively reduce GAS illness in US military training centres (3,8-14). The two antibiotics that are used in MAP are intramuscular penicillin G benzathine (PGB) and oral azithromycin. Commonly reported adverse events in adults for injected PGB include local injection site reactions including pain, rash, joint disorder and dizziness (15). The most commonly reported adverse events in adults following oral 
azithromycin administration were diarrhea/loose stools (4\%-5\%) nausea (3\%-4\%), abdominal pain (2\%-3\%) and vomiting (1\%) (16). However, the impact of adverse events following MAP administration to US military recruits has not been published.

The Canadian Forces Leadership and Recruit School (CFLRS) is the basic military training (BMT) facility for the Canadian Armed Forces (CAF). Each year, CFLRS provides BMT to approximately 4,400 CAF recruits, in a facility housing up to 1,500 recruits at a time (Maj E. Girard, personal communication, March 29, 2019).

The training is an intense structured ten to twelve-week program and any lapses in training may contribute to a military recruit failing or having to retake the course. Between December 2016 and March 2018, there were two GAS outbreaks of the laboratory confirmed strain emm6.4 (17).

Because of these two GAS outbreaks occurring within a ten-month period, Canadian Forces Health Services, in consultation with the regional and provincial civilian public health agencies, decided to implement a voluntary MAP program with the objective of interrupting the outbreak and preventing future spread of GAS among military personnel at CFLRS. This marked the first time a MAP program for a GAS outbreak had ever been implemented in CAF. Given the potential adverse events of the antibiotics used for MAP, a lack of published literature examining its effects on military recruits, and the deleterious impact that this might have on a recruit's ability to successfully complete BMT, the present study examines the short-term adverse outcomes experienced by recruits in CAF and their impact on BMT, as a result of MAP.

\section{Methods}

A voluntary MAP program was implemented between March 7, 2018 and May 28, 2018 at the CFLRS, located in Saint-Jean-sur-Richelieu, Québec (Canada). Recruits and instructors were offered a one-time intramuscular injection of 1.2 million units of PGB. PGB was administered intramuscularly into the vastus lateralis for personnel treated March 7-April 22, 2018. Because of a revision of the product monograph, PGB was administered into the dorsogluteal site for personnel treated April 23-May 28, 2018. Individuals reporting a penicillin allergy or refusing PBG were offered azithromycin $500 \mathrm{mg}$ orally once weekly for four consecutive weeks. Recruits and instructors were provided with drug information sheets, available in both official languages (French and English).

A voluntary and anonymous paper-based survey was developed to conduct surveillance of adverse events following MAP. The survey was available in both official languages and consisted of 14 non-demographic questions (Supplemental 1). The survey was offered one week after the administration of PGB or one week after the first oral dose of azithromycin. Survey respondents were asked to self-report the type of antibiotic received, whether they experienced any of the common side effects listed on the antibiotics' respective product monographs, and whether these side effects limited their participation in BMT. Completed surveys were returned to the Directorate Force Health Protection by internal mail. Data were manually entered into an Access database, and a random 10\% sample of surveys $(n=145)$ were reentered to ensure accurate data entry by multiple personnel. In addition, passive surveillance using a line listing formatted spreadsheet was developed for local clinicians to provide information on personnel who were assessed for severe or unusual adverse events following MAP.

\section{Results}

From March 7 to May 28, 2018, MAP was offered to 2,534 recruits and 215 instructors (Table 1). Overall, it was administered to 2,707 CAF personnel (98.5\% uptake). Of the 2,707 individuals who were administered MAP, 2,398 (88.6\%) received PGB and the other 309 (11.2\%) received azithromycin.

\section{Table 1: Frequency of recruits and instructors accepting or refusing mass antibiotic prophylaxis at the Canadian Forces Leadership and Recruit School, March 7-April 30, 2018}

\begin{tabular}{|l|r|c|r|c|r|r|r|}
\multirow{2}{*}{$\begin{array}{c}\text { Staff } \\
\text { administered }\end{array}$} & \multicolumn{2}{|c|}{ PGB } & \multicolumn{2}{c|}{ Azithromycin } & \multicolumn{2}{c|}{ Refusals } & \multirow{2}{*}{ Total } \\
\cline { 2 - 7 } & $\mathbf{n}$ & $\%$ & \multicolumn{1}{c|}{$\mathbf{n}$} & \multicolumn{1}{c|}{$\%$} & \multicolumn{1}{c|}{$\mathbf{n}$} & $\%$ & \\
\hline Recruit & 2,226 & 87.8 & 281 & 11.1 & 27 & 1.1 & 2,534 \\
\hline Instructor & 172 & 80.0 & 28 & 13.0 & 15 & 7.0 & 215 \\
\hline Total & 2,398 & 87.2 & 309 & 11.2 & 42 & 1.5 & 2,749 \\
\hline Abbreviation: PGB, penicillin G benzathine & \multicolumn{7}{|c|}{}
\end{tabular}

\section{Outcomes-adverse events surveillance}

During the period of March 14 to May 7, 2018, 2,149 CAF personnel received a MAP adverse events survey. The survey was completed by 1,752 individuals ( $81.5 \%$ response rate), but 41 respondents were excluded from analysis because of missing data (29 did not indicate which antibiotic they received and 12 did not indicate if they were a recruit or instructor). Of the 1,711 individuals, another 41 respondents were excluded because they indicated that they had refused MAP or that MAP had not been offered to them (Table 2). The remaining 1,670 respondent were included in the analysis of adverse events.

Of the 1,670 survey respondents, 1,462 (87.5\%) received PGB. Among them, 1,358 (92.9\%) reported at least one adverse event. The adverse event most commonly reported after PGB injection was localised pain at the injection site (Table 3). Twenty recruits and three instructors (i.e. $1.6 \%$ of all respondents treated with PGB) sought medical attention for their pain (Table 3 ). Respondents who received a PGB injection in the vastus lateralis had significantly higher odds of reporting pain than those who received the injection in the gluteal muscle $(2.45 ; 95 \% \mathrm{Cl}$, 1.76-3.42; $p=0.002$ ). Four recruit respondents reported having failed BMT, and another seven reported having to retake the 
Table 2: Number of adverse events reported ${ }^{a}$ following mass antibiotic prophylaxis antibiotics for recruits and instructors at the Canadian Forces Leadership and Recruit School, March 7-April 30, 2018

\begin{tabular}{|c|c|c|c|c|c|c|c|}
\hline \multirow{2}{*}{$\begin{array}{c}\text { Staff } \\
\text { administered }\end{array}$} & \multicolumn{2}{|c|}{ PGB } & \multicolumn{2}{|c|}{ Azithromycin } & \multicolumn{2}{|c|}{$\begin{array}{c}\text { No } \\
\text { MAPb }\end{array}$} & \multirow{2}{*}{ Total } \\
\hline & $\mathbf{n}$ & $\%$ & $n$ & $\%$ & n & $\%$ & \\
\hline Recruit & 1,358 & 86.6 & 183 & 11.7 & 27 & 1.7 & 1,568 \\
\hline Instructor & 104 & 72.7 & 25 & 17.5 & 14 & 9.8 & 143 \\
\hline Total & 1,462 & 85.4 & 208 & 12.2 & 41 & 2.4 & 1,711 \\
\hline
\end{tabular}

Abbreviations: MAP, mass antibiotic prophylaxis; PGB, penicillin $\mathrm{G}$ benzathine

a Self-reported in adverse events survey one week after treatment

Refused or not offered

course, as a consequence of an adverse event following a PGB injection; together, these 11 respondents represent $0.8 \%$ of the 1,358 recruit respondents who reported receiving a PGB injection. Recruits $(30.6 \% ; 95 \% \mathrm{Cl}, 28.2-33.2)$ and instructors (27.9\%; $95 \% \mathrm{Cl}, 20.1-37.3)$ reported experiencing pain most commonly at the injection site for three days with approximately $50 \%$ of recruits and instructors reporting that the most intense day of pain was the first day after the injection.
Of the 1,670 survey respondents, $208(12.5 \%)$ received azithromycin. Among them, 146 (70.2\%) reported experiencing at least one gastrointestinal (GI) symptom after their first dose of the antibiotic. Reported Gl symptoms included diarrhea, stomach pain and nausea or vomiting (Table 4). The Gl symptoms were most frequently reported on the first day after receiving the first dose of the oral antibiotic (Table 4). Two recruits respondents reported having failed BMT, and one other reported having to retake the course, as a consequence of an adverse event of azithromycin; together, these three individuals represent $1.6 \%$ of the 183 recruits respondents who reported receiving an oral dose of azithromycin.

Of the 2,707 individuals who received MAP, there was a total of five reported cases of serious adverse events requiring hospitalization (four recruits and one instructor), all following PGB injection in March 2018. The five adverse events included one case of each of the following: anaphylaxis, compartment syndrome (rhabdomyolysis with acute renal injury), cellulitis, hematoma at injection site and excessive vomiting. Hospitalization duration ranged from one day (anaphylaxis, hematoma, excessive vomiting) to several days (cellulitis, rhabdomyolysis), with all five individuals recovering fully.

Table 3: Summary of self-reported adverse events and seeking of medical assistance by recruits and instructors at the Canadian Forces Leadership and Recruit School following injection of penicillin G benzathine, March 7-April 30, 2018

\begin{tabular}{|c|c|c|c|c|c|c|c|c|c|c|c|c|}
\hline \multirow{2}{*}{$\begin{array}{l}\text { Staff self- } \\
\text { reporting }\end{array}$} & \multicolumn{2}{|c|}{$\begin{array}{c}\text { Pain at injection } \\
\text { site }\end{array}$} & \multicolumn{2}{|c|}{ Headache } & \multicolumn{2}{|c|}{$\begin{array}{c}\text { Nausea or } \\
\text { vomiting }\end{array}$} & \multicolumn{2}{|c|}{$\begin{array}{l}\text { Rash or } \\
\text { itchiness }\end{array}$} & \multicolumn{2}{|c|}{$\begin{array}{c}\text { Dizziness or } \\
\text { lightheadedness }\end{array}$} & \multicolumn{2}{|c|}{ Joint pain } \\
\hline & $\mathbf{n}$ & $\begin{array}{c}(\%, 95 \% \\
\mathrm{Cl})\end{array}$ & $\mathbf{n}$ & $\begin{array}{c}(\%, 95 \% \\
\mathrm{Cl})\end{array}$ & $\mathbf{n}$ & $\begin{array}{c}(\%, 95 \% \\
\mathrm{CI})\end{array}$ & $\mathbf{n}$ & $\begin{array}{c}(\%, 95 \% \\
\mathrm{Cl})\end{array}$ & $\mathbf{n}$ & $\begin{array}{c}(\%, 95 \% \\
\mathrm{Cl})\end{array}$ & $\mathbf{n}$ & $\begin{array}{c}(\%, 95 \% \\
\mathrm{CI})\end{array}$ \\
\hline Recruits & 1,248 & $\begin{array}{r}(92.2 \\
90.7-93.5) \\
\end{array}$ & 225 & $\begin{array}{r}(17.4 \\
15.4-19.5) \\
\end{array}$ & 96 & $\begin{array}{r}(7.5 \\
6.2-9.1) \\
\end{array}$ & 84 & $\begin{array}{r}(6.6, \\
5.3-8.1) \\
\end{array}$ & 223 & $\begin{array}{r}(17.3 \\
15.4-19.5) \\
\end{array}$ & 298 & $\begin{array}{r}(22.7 \\
20.5-25.0) \\
\end{array}$ \\
\hline Instructors & 98 & $\begin{array}{r}(94.2 \\
88.0-97.3)\end{array}$ & 16 & $\begin{array}{r}(15.8 \\
10.0-24.2)\end{array}$ & 4 & $\begin{array}{r}(4.0 \\
1.6-9.9)\end{array}$ & 4 & $\begin{array}{r}(4.1, \\
1.6-10.1)\end{array}$ & 12 & $\begin{array}{r}(11.9 \\
6.9-19.6)\end{array}$ & 21 & $\begin{array}{r}(20.6, \\
13.9-29.4)\end{array}$ \\
\hline Total & 1,346 & $\begin{array}{r}(92.3 \\
90.8-93.6)\end{array}$ & 241 & $\begin{array}{r}(17.3 \\
15.4-19.3)\end{array}$ & 100 & $\begin{array}{r}(7.3 \\
6.0-8.8) \\
\end{array}$ & 88 & $\begin{array}{r}(6.4 \\
5.2-7.8)\end{array}$ & 235 & $\begin{array}{r}(16.9 \\
15.1-19.0)\end{array}$ & 319 & $\begin{array}{r}(22.5, \\
20.4-24.8)\end{array}$ \\
\hline $\begin{array}{l}\text { Number } \\
\text { of days } \\
\text { experiencing } \\
\text { adverse event }\end{array}$ & & 3 & & 1 & & 1 & & 1 & & 1 & & 2 \\
\hline $\begin{array}{l}\text { Recruits- } \\
\text { Sought } \\
\text { medical help } \\
\text { as a result of } \\
\text { adverse event }\end{array}$ & 20 & $\begin{array}{r}(1.7 \\
1.1-2.6)\end{array}$ & 8 & $\begin{array}{r}(4.0 \\
2.0-7.8)\end{array}$ & 5 & $\begin{array}{r}(5.7 \\
2.3-13.1)\end{array}$ & 6 & $\begin{array}{r}(9.5 \\
4.2-20.0)\end{array}$ & 15 & $\begin{array}{r}(7.7 \\
4.7-12.4)\end{array}$ & 13 & $\begin{array}{r}(5.1, \\
2.9-8.5)\end{array}$ \\
\hline $\begin{array}{l}\text { Instructors- } \\
\text { Sought } \\
\text { medical help } \\
\text { as a result of } \\
\text { adverse event }\end{array}$ & 3 & $\begin{array}{r}(3.1 \\
1.0-9.3)\end{array}$ & 0 & $\begin{array}{r}(0, \\
0.0)\end{array}$ & 0 & $\begin{array}{r}(0, \\
0.0)\end{array}$ & 0 & $\begin{array}{r}(0, \\
0.0)\end{array}$ & 0 & $\begin{array}{r}(0, \\
0.0)\end{array}$ & 1 & $\begin{array}{r}(5.3 \\
0.7-30.7)\end{array}$ \\
\hline $\begin{array}{l}\text { Recruits } \\
\text { reporting } \\
\text { receiving sick } \\
\text { leave }\end{array}$ & $\begin{array}{r}16 \text { out } \\
\text { of } 18\end{array}$ & $\begin{array}{r}(88.9, \\
61.1-97.6)\end{array}$ & $\begin{array}{l}2 \text { out } \\
\text { of } 7\end{array}$ & $\begin{array}{r}(28.6 \\
4.2-78.5)\end{array}$ & $\begin{array}{l}2 \text { out } \\
\text { of } 3\end{array}$ & $\begin{array}{r}(66.7 \\
20.8-93.9)\end{array}$ & $\begin{array}{l}2 \text { out } \\
\text { of } 4\end{array}$ & $\begin{array}{r}(50, \\
15.0-85.0)\end{array}$ & $\begin{array}{l}6 \text { out } \\
\text { of } 11\end{array}$ & $\begin{array}{r}(54.5 \\
22.6-83.2)\end{array}$ & $\begin{array}{l}7 \text { out } \\
\text { of } 11\end{array}$ & $\begin{array}{r}(63.6, \\
28.8-88.3)\end{array}$ \\
\hline
\end{tabular}


Table 4: Summary of self-reported adverse events and seeking of medical assistance following administration of azithromycin ${ }^{a}$ for those personnel at the Canadian Forces Leadership and Recruit School, March 7-April 30, 2018

\begin{tabular}{|c|c|c|c|c|c|c|}
\hline \multirow{2}{*}{$\begin{array}{l}\text { Staff self- } \\
\text { reporting }\end{array}$} & \multicolumn{2}{|c|}{ Diarrhea } & \multicolumn{2}{|c|}{ Stomach pain } & \multicolumn{2}{|c|}{$\begin{array}{c}\text { Nausea or } \\
\text { vomiting }\end{array}$} \\
\hline & $\mathbf{n}$ & $\begin{array}{c}(\%, \\
95 \% \mathrm{Cl})\end{array}$ & n & $\begin{array}{c}(\%, \\
95 \% \mathrm{Cl})\end{array}$ & n & $\begin{array}{c}(\%, \\
95 \% \mathrm{Cl})\end{array}$ \\
\hline Recruits & 78 & $\begin{array}{r}(47.3 \\
39.8-54.9) \\
\end{array}$ & 91 & $\begin{array}{r}(53.2 \\
45.8-60.5)\end{array}$ & 57 & $\begin{array}{r}(35.0, \\
28.1-42.6)\end{array}$ \\
\hline Instructors & 14 & $\begin{array}{r}(60.9 \\
40.8-77.8)\end{array}$ & 15 & $\begin{array}{r}(65.2 \\
44.9-81.2)\end{array}$ & 5 & $\begin{array}{r}(25.0 \\
11.2-46.9)\end{array}$ \\
\hline Total & 92 & $\begin{array}{r}(48.9 \\
41.9-56.0)\end{array}$ & 106 & $\begin{array}{r}(54.6 \\
47.6-61.5)\end{array}$ & 62 & $\begin{array}{r}\text { (33.9, } \\
27.4-41.0)\end{array}$ \\
\hline $\begin{array}{l}\text { Recruits- } \\
\text { Sought } \\
\text { medical help } \\
\text { as a result } \\
\text { of adverse } \\
\text { event }\end{array}$ & 1 & $\begin{array}{r}(1.4 \\
0.2-7.4)\end{array}$ & 2 & $\begin{array}{r}(2.4 \\
0.7-8.2)\end{array}$ & 3 & $\begin{array}{r}(5.3 \\
1.8-14.4)\end{array}$ \\
\hline $\begin{array}{l}\text { Instructors- } \\
\text { Sought } \\
\text { medical help } \\
\text { as a result } \\
\text { of adverse } \\
\text { event }\end{array}$ & & 0 & & 0 & & 0 \\
\hline $\begin{array}{l}\text { Recruits } \\
\text { reporting } \\
\text { receiving sick } \\
\text { leave }\end{array}$ & None & $(0.0)$ & $\begin{array}{l}1 \text { out } \\
\text { of } 2\end{array}$ & $\begin{array}{r}(50.0 \\
9.5-90.6)\end{array}$ & $\begin{array}{l}2 \text { out } \\
\text { of } 3\end{array}$ & $\begin{array}{r}(66.7 \\
20.8-93.9)\end{array}$ \\
\hline
\end{tabular}

${ }^{a}$ Azithromycin administered as one oral dose-the first of four doses in a full treatment regime

\section{Discussion}

\section{Summary of findings}

In March 2018, a voluntary MAP program was implemented in CFLRS. Based on self-reported surveys, the majority of personnel experienced adverse events in the first week following MAP; 92.3\% of personnel who were injected with PGB reported pain at the injection site, and $70.2 \%$ of personnel who were administered azithromycin orally reported Gl symptoms after their first dose. However, few of these adverse events appear to have caused significant impact on personnel. Only five serious adverse events were reported in the first month following MAP, and less than $1 \%$ of recruits reported being unable to complete BMT as a consequence of MAP.

\section{Comparison to the literature}

The reported adverse events from MAP are consistent with those cited in the drug monographs, including the two most commonly reported adverse events: localised pain following PGB injection and $\mathrm{Gl}$ symptoms following an oral dose of azithromycin $(15,16)$. There were no new unknown adverse events reported by recruits for either antibiotic. Only $0.8 \%$ of CAF recruits who received PGB reported an adverse event that resulted in them failing or having to retake BMT.
Surprisingly, the Gl symptoms reported by the military recruits who took azithromycin were a magnitude of ten higher than those cited in the monograph (16), which may reflect recall bias especially since the survey was administered one week following MAP. However, the impact on recruit training was minimal since only $1.6 \%$ of recruits who received azithromycin reported having failed or having to retake BMT, which is comparable to the reported $1 \%$ severe and/or life-threatening adverse events (16).

Rates of serious adverse events were associated with injected PGB administered only during the first month of MAP

(March 7-April 22) (0.15\%), which is also consistent with previous studies. For example, of the 2,398 personnel injected with PGB, only one had an anaphylactic reaction ( $n=1 / 2,398,0.04 \%)$. Similarly, in a US study of 199,862 patients followed for the first 14 days after the administration of penicillin, $0.05 \%$ experienced a serious allergic reaction (18). For the past 20 years, there have been no reported cases of anaphylaxis associated with chemoprophylaxis in US military training centres (9).

\section{Strengths and weaknesses}

Following the implementation of MAP at CFLRS, there were no new cases of iGAS or severe GAS and there was a precipitous decrease in the number of GAS-positive throat swabs. However, there continued to be adenovirus outbreaks among military recruits. This program is year-round now, which has implications for staffing resources for the administration and timing of mass antibiotic administration, so as to minimize its impact on BMT.

\section{Implications}

Although no serious adverse events associated with azithromycin were reported in this intervention, PGB is still the preferred choice of chemoprophylaxis over azithromycin, for several reasons. These reasons include concerns about resistance to azithromycin by GAS $(19,20)$ and other pathogens, such as Streptococcus pneumoniae (21), cardiac arrest due to elongation of the QT interval (22) and increased compliance with one time PGB dosing compared to multiple doses required with oral azithromycin (6). Direct observed therapy has been implemented in US military training centres because of non-compliance with this oral antibiotic.

Because of the high prevalence of self-reported pain at the PGB injection site, leadership postponed mandatory fitness testing for the first 24 hours post-injection in order to minimize exacerbation of the localised injection site pain (Maj E. Girard, personal communication, March 29, 2019).

\section{Limitations of the survey}

It should be noted that, given the urgent need to implement MAP during the GAS outbreak at CFLRS, the adverse event survey could not be validated prior to its administration. Some survey questions may therefore have been unclear to respondents. For example, recruits and instructors reported not having sought medical attention, but having been excused 
from duty, because of MAP-related adverse events. This is contradictory, because military personnel can only be excused from duty if they are assessed in clinic. Additionally, information such as gender and age was not obtained in the survey, so we were not able to determine if there were any differences in adverse events because of demographic differences.

Furthermore, survey respondents may have incorrectly recalled the type of antibiotic received. As part of BMT, recruits often receive a number of immunizations, which respondents could have confused for injectable PGB. Because of the anonymous nature of the adverse event survey, it was impossible to confirm the accuracy of self-reported data on the type of antibiotic administered.

Lastly, PGB injections were administered by CAF clinical staff, but azithromycin doses were self-administered over four consecutive weeks. Personnel who were prescribed azithromycin were not observed taking their antibiotic, and compliance is therefore unknown. Furthermore, the adverse event survey was only administered one week after the first azithromycin dose. It is therefore possible that the survey underestimated the true risk of adverse events associated with the use of azithromycin as a prophylaxis to treat GAS.

\section{Conclusion}

The intervention described herein corresponds to the first time that MAP had been implemented in CAF, and is the largest single use of PGB in a defined group in Canada. This intervention, which interrupted the ongoing GAS outbreak, was generally well tolerated by both recruits and instructors, with minimal impact on the ability of recruits to complete their BMT. Common adverse events were reported, as expected, with the use of both PGB and azithromycin although serious adverse events were rare. Thus, MAP can be used safely to reduce the spread of GAS among CAF personnel and protect recruits against serious GAS infections.

\section{Authors' statement}

$\mathrm{DL}$ - Conceptualization of manuscript, original draft, review and editing of manuscript

BS - Data curation, formal analysis, review and editing of manuscript

KS - Conceptualization and drafting of survey, data curation, formal analysis, review and editing of manuscript

MT - Review and editing of manuscript

FG - Formatting and administration of survey, review and

editing of manuscript

NJ - Administration of survey, review and editing of manuscript

EG - Review and editing of manuscript

$\mathrm{KB}$ - Review and editing of manuscript

\section{Competing interests}

Previously presented as a podium presentation at the Canadian Institute for Military and Veteran Health Research (CIMVHR) 2018

Forum, Regina, Saskatchewan, October 15, 2018.
Disclaimer: The views expressed are solely those of the authors and do not reflect the official policy or position of the Canadian Armed Forces or the Government of Canada.

\section{Acknowledgments}

We would like to thank Dr. M St. Amour for her contributions to this outbreak investigation. As well, we would like to acknowledge the collaborative efforts of all the clinical staff at 41 Centre des Services de santé des Forces canadiennes, St-Jean-sur-Richelieu who administered the mass antibiotic prophylaxis and the adverse events survey. Finally, thank you to the epidemiology staff that entered the data from the adverse events survey, Dr. F Thériault and Dr. H McCuaig Edge for reviewing this manuscript and $\mathrm{S}$ Carlucci for assistance with the references.

\section{Funding}

None.

\section{References}

1. Levinson W. Review of Medical Microbiology \& Immunology. $12^{\text {th }}$ ed. New York: McGraw-Hill Medical; 2012.

2. Heymann DL. Streptococcal diseases. In: Heymann DL, editor. Control of Communicable Disease Manual. 20 ${ }^{\text {th }}$ ed. Washington DC: American Public Health Association; 2015. p 581-9

3. Bernstein $\mathrm{SH}$, Feldman HA, Harper OF Jr, Klingensmith WH. Massoral penicillin prophylaxis in control of streptococcal disease. AMA Arch Intern Med 1954;93(6):894-8. DOI PubMed

4. Sanchez JL, Cooper MJ, Myers CA, Cummings JF, Vest KG, Russell KL, Sanchez JL, Hiser MJ, Gaydos CA. Respiratory infections in the U.S. Military: recent experience and control. Clin Microbiol Rev 2015;28(3):743-800. DOI PubMed

5. Lee SE, Eick A, Ciminera P. Respiratory disease in Army recruits: surveillance program overview, 1995-2006. Am J Prev Med 2008;34(5):389-95. DOI PubMed

6. Crum NF, Russell KL, Kaplan EL, Wallace MR, Wu J, Ashtari $P_{\text {, }}$ Morris DJ, Hale BR. Pneumonia outbreak associated with group a Streptococcus species at a military training facility. Clin Infect Dis 2005;40(4):511-8. DOI PubMed

7. Gray GC, Callahan JD, Hawksworth AW, Fisher CA, Gaydos JC. Respiratory diseases among U.S. military personnel: countering emerging threats. Emerg Infect Dis 1999;5(3):379-87. DOl PubMed

8. Lazar HP, Maas GI, Harrison W, Hammond JH, Rantz LA. Streptococcal disease and rheumatic fever in Air Force recruits. II. Prophylaxis with tandem oral penicillin. AMA Arch Intern Med 1957;100(4):614-9. DOI PubMed 
9. Webber BJ, Kieffer JW, White BK, Hawksworth AW, Graf PC, Yun HC. Chemoprophylaxis against group A streptococcus during military training. Prev Med 2019;118:142-9. DOI PubMed

10. Schreier AJ, Hockett VE, Seal JR. Mass prophylaxis of epidemic streptococcal infections with benzathine penicillin G.I. Experience at a naval training center during the winter of 1955-56. N Engl J Med 1958;258(25):1231-8. DOI PubMed

11. McFarland RB, Colvin VG, Seal JR. Mass prophylaxis of epidemic streptococcal infections with benzathine penicillin G.-Experience at a naval training center during the winter of 1956-57. N Engl J Med 1958 Jun;258(26):1277-84. DOI PubMed

12. Basiliere JL, Bistrong HW, Spence WF. Streptococcal pneumonia. Recent outbreaks in military recruit populations. Am J Med 1968;44(4):580-9. DOI PubMed

13. Thomas RJ, Conwill DE, Morton DE, Brooks TJ, Holmes CK, Mahaffey WB. Penicillin prophylaxis for streptococcal infections in United States Navy and Marine Corps recruit camps, 1951-1985. Rev Infect Dis 1988;10(1):125-30. DOI PubMed

14. Centers for Disease Control (CDC). Group A beta-hemolytic streptococcal pharyngitis among U.S. Air Force trainees-Texas, 1988-89. MMWR Morb Mortal Wkly Rep 1990;39(1):11-3. PubMed

15. Penicillin $G$ benzathine drug monograph (accessed 2019-0305). https://www.pfizer.ca/sites/g/files/g10050796/f/201710/ Bicillin_PM.pdf

16. Azithromycin drug monograph (accessed 2019-03-05). https://www.sandoz.ca/sites/www.sandoz.ca/files/ Sandoz\%20Azithromycin\%20PM_EN.pdf
17. Hammond-Collins K, Strauss B, Barnes K, Demczuk W, Domingo MC, Lamontagne MC, Lu D, Martin I, Tepper M, Group A. Group A Streptococcus Outbreak in a Canadian Armed Forces Training Facility. Mil Med 2019;184(3-4):e197-204. DOl PubMed

18. Johannes CB, Ziyadeh N, Seeger JD, Tucker E, Reiter C, Faich $\mathrm{G}$. Incidence of allergic reactions associated with antibacterial use in a large, managed care organisation. Drug Saf 2007;30(8):705-13. DOI PubMed

19. Barrozo CP, Russell KL, Smith TC, Hawksworth AW, Ryan MA, Gray GC. National Department of Defense surveillance data for antibiotic resistance and emm gene types of clinical group A streptococcal isolates from eight basic training military sites. J Clin Microbiol 2003;41(10):4808-11. DO| PubMed

20. Metzgar D, McDonough EA, Hansen CJ, Blaesing CR, Baynes D, Hawksworth AW, Blair PJ, Faix DJ, Russell KL. Local changes in rates of group A Streptococcus disease and antibiotic resistance are associated with geographically widespread strain turnover events. Virulence 2010;1(4):24753. DOl PubMed

21. Gray GC, Witucki PJ, Gould MT, Bell SJ, Hiliopoulos KM, McKeehan JA, Fuller JM, Barrozo CP, Hudspeth MK, Smith TC, Ledbetter EK, Wallace MR. Randomized, placebo-controlled clinical trial of oral azithromycin prophylaxis against respiratory infections in a high-risk, young adult population. Clin Infect Dis 2001;33(7):983-9. DOI PubMed

22. Goldstein EJC, Jr Owens RC, Nolin TD.

Antimicrobial-associated QT interval prolongation: pointes of interest. Clin Infect Dis 2006:43(12):1603-11.

DOI PubMed

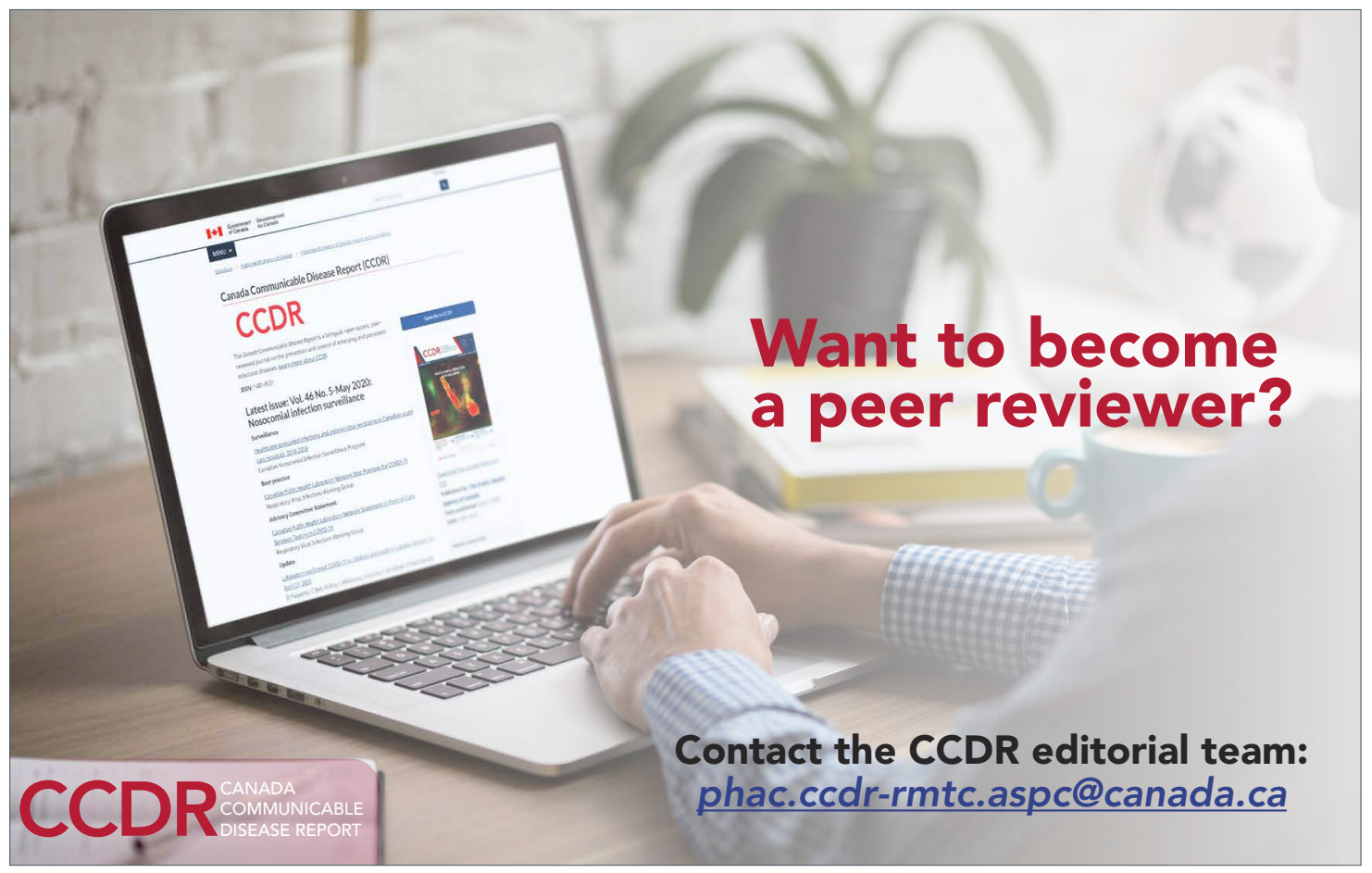




\section{Annex: Survey of adverse reactions - antibiotic prophylaxis at Canadian Forces Leadership and Recruit School}

\section{Introduction:}

Over the past few weeks, you may have been offered one of two medications (antibiotics) to prevent you from becoming ill from an infection called Group A Streptococcus. We would like to know your experience with any side effects from these medications by answering a few questions. Please note that this survey is voluntary and anonymous.

\section{Instructions:}

Please circle the answer that best applies to you.

When complete, please hand in this form to your Directing Staff.

\section{PART A - ANTIBIOTICS}

1. Which antibiotic did you receive?
a. Bicillin (injection)
b. Azithromycin (pill)
[Answer only part B]
c. Neither (declined antibiotics or was not offered)
[Answer only part C]
d. Unsure
[STOP survey here]
[STOP survey here]

Pain at Injection Site

\section{PART B - BICILLIN (INJECTION)}

2. For how many days did you experience pain where you received the injection?

\begin{tabular}{|c|c|c|c|c|c|c|}
\hline No pain & 1 day & 2 days & 3 days & 4 days & 5 days & 6 days or more \\
\hline
\end{tabular}

3. On which day was the pain the most intense?

\begin{tabular}{|c|c|c|c|c|c|c|c|}
\hline No pain & $\begin{array}{c}\text { The same } \\
\text { day }\end{array}$ & $\begin{array}{c}1 \text { day } \\
\text { after }\end{array}$ & $\begin{array}{c}2 \text { days } \\
\text { after }\end{array}$ & $\begin{array}{c}3 \text { days } \\
\text { after }\end{array}$ & $\begin{array}{c}4 \text { days } \\
\text { after }\end{array}$ & $\begin{array}{c}5 \text { days } \\
\text { after }\end{array}$ & 6 days or more after \\
\hline
\end{tabular}

4. Did you seek medical help due to pain where you received the injection?

\begin{tabular}{|c|c|c|}
\hline No pain & Yes & No \\
\hline
\end{tabular}

5. If "Yes" to Question 4, on what day did you seek medical help after the injection?

\begin{tabular}{|c|c|c|c|c|c|c|}
\hline $\begin{array}{c}\text { The same } \\
\text { day }\end{array}$ & 1 day after & $\begin{array}{c}2 \text { days } \\
\text { after }\end{array}$ & $\begin{array}{c}3 \text { days } \\
\text { after }\end{array}$ & $\begin{array}{c}4 \text { days } \\
\text { after }\end{array}$ & $\begin{array}{c}5 \text { days } \\
\text { after }\end{array}$ & 6 days or more after \\
\hline
\end{tabular}

6. Did you obtain a chit with medical limitations (restricting you from doing activities scheduled in your recruit routine) due to pain where you received the injection?

\begin{tabular}{l|l|l} 
No pain & Yes & No
\end{tabular}

\section{Other symptoms}

7. Did you experience any of the following symptoms after the injection?

If yes, please indicate for how many days you experienced these other symptoms.

\begin{tabular}{|c|c|c|c|c|c|c|c|}
\hline Symptoms & $\begin{array}{c}\text { Did not } \\
\text { experience }\end{array}$ & $\begin{array}{c}\mathbf{1} \text { day or } \\
\text { less }\end{array}$ & $\mathbf{2}$ days & $\mathbf{3}$ days & $\mathbf{4}$ days & $\mathbf{5}$ days & $\begin{array}{c}\mathbf{6} \text { days } \\
\text { or } \text { more }\end{array}$ \\
\hline Headache & $\mathrm{O}$ & $\mathrm{O}$ & $\mathrm{O}$ & $\mathrm{O}$ & $\mathrm{O}$ & $\mathrm{O}$ & $\mathrm{O}$ \\
\hline Nausea or vomiting & $\mathrm{O}$ & $\mathrm{O}$ & $\mathrm{O}$ & $\mathrm{O}$ & $\mathrm{O}$ & $\mathrm{O}$ & $\mathrm{O}$ \\
\hline Skin rash or itchiness & $\mathrm{O}$ & $\mathrm{O}$ & $\mathrm{O}$ & $\mathrm{O}$ & $\mathrm{O}$ & $\mathrm{O}$ & $\mathrm{O}$ \\
\hline $\begin{array}{c}\text { Dizziness or } \\
\text { lightheadedness }\end{array}$ & $\mathrm{O}$ & $\mathrm{O}$ & $\mathrm{O}$ & $\mathrm{O}$ & $\mathrm{O}$ & $\mathrm{O}$ & $\mathrm{O}$ \\
\hline Joint and bone pain & $\mathrm{O}$ & $\mathrm{O}$ & $\mathrm{O}$ & $\mathrm{O}$ & $\mathrm{O}$ & $\mathrm{O}$ & $\mathrm{O}$ \\
\hline
\end{tabular}


8. Did you seek medical help due to any of these other symptoms?

\begin{tabular}{|c|c|c|c|}
\hline Symptoms & I did not have this symptom & Yes & No \\
\hline Headache & 0 & 0 & 0 \\
\hline Nausea or vomiting & 0 & 0 & 0 \\
\hline Skin rash or itchiness & 0 & 0 & 0 \\
\hline Dizziness or lightheadedness & 0 & 0 & 0 \\
\hline Joint and bone pain & 0 & 0 & 0 \\
\hline
\end{tabular}

9. Did you obtain a chit with medical limitations (restricting you from doing some of the activities scheduled in your recruit routine) due to any of these other symptoms?

\begin{tabular}{|c|c|c|c|}
\hline Symptoms & I did not have this symptom & Yes & No \\
\hline Headache & 0 & 0 & 0 \\
\hline Nausea or vomiting & 0 & 0 & 0 \\
\hline Skin rash or itchiness & 0 & 0 & 0 \\
\hline Dizziness or lightheadedness & 0 & 0 & 0 \\
\hline Joint and bone pain & 0 & 0 & 0 \\
\hline
\end{tabular}

10. Did you fail recruit training or were you recoursed as a result of side effects from bicillin (injection)? No Fail Recourse

\section{PART C - AZITHROMYCIN (PILL)}

11. Did you experience any of the following after taking a dose (pill) of azithromycin? If yes, please indicate how many days you experienced these symptoms.

\begin{tabular}{|c|c|c|c|c|c|c|c|}
\hline Symptoms & $\begin{array}{l}\text { I did not have } \\
\text { this symptom }\end{array}$ & $\begin{array}{c}\mathbf{1} \text { day or } \\
\text { less }\end{array}$ & $\mathbf{2}$ days & $\mathbf{3}$ days & $\mathbf{4}$ days & $\mathbf{5}$ days & $\begin{array}{c}\mathbf{6} \text { days or } \\
\text { more }\end{array}$ \\
\hline Diarrhea & $\mathrm{O}$ & $\mathrm{O}$ & $\mathrm{O}$ & $\mathrm{O}$ & $\mathrm{O}$ & $\mathrm{O}$ & $\mathrm{O}$ \\
\hline Stomach pain & $\mathrm{O}$ & $\mathrm{O}$ & $\mathrm{O}$ & $\mathrm{O}$ & $\mathrm{O}$ & $\mathrm{O}$ & $\mathrm{O}$ \\
\hline Nausea or vomiting & $\mathrm{O}$ & $\mathrm{O}$ & $\mathrm{O}$ & $\mathrm{O}$ & $\mathrm{O}$ & $\mathrm{O}$ & $\mathrm{O}$ \\
\hline
\end{tabular}

12. Did you seek medical help due to diarrhea, stomach pain, or nausea/vomiting?

\begin{tabular}{|c|c|c|c|}
\hline Symptoms & I did not have this symptom & Yes & No \\
\hline Diarrhea & O & 0 & 0 \\
\hline Stomach pain & 0 & 0 & 0 \\
\hline Nausea or vomiting & O & 0 & 0 \\
\hline
\end{tabular}

13. Did you obtain a chit with medical limitations (restricting you from doing some of the activities scheduled in your recruit routine) due to diarrhea, stomach pain, or nausea/vomiting?

\begin{tabular}{|c|c|c|c|}
\hline Symptoms & I did not have this symptom & Yes & No \\
\hline Diarrhea & O & 0 & 0 \\
\hline Stomach pain & O & 0 & 0 \\
\hline Nausea or vomiting & O & 0 & 0 \\
\hline
\end{tabular}

14. Did you fail recruit training or were you recoursed as a result of side effects from azithromycin (pill)?

\begin{tabular}{|c|c|c|}
\hline No & Fail & Recourse \\
\hline
\end{tabular}

If you have any health concerns regarding these medications, please seek medical attention. Maj François Gagnon, MD, Base Surgeon 41 CF H Svc C St-Jean-sur-Richelieu, (450) 358-7099 poste 6236 